\title{
KAMPANYE DAN PERTARUNGAN POLITIK DI JAWA TENGAH MENJELANG PEMILIHAN UMUM 1955
}

\author{
Tsabit Azinar Ahmad \\ Jurusan Sejarah, Fakultas Ilmu Sosial, Universitas Negeri Semarang \\ azinarahmad@mail.unnes.ac.id
}

\begin{abstract}
Through study of campaign discourse from various documents, this research tries to explain political constellation and discourse in Cenral Java toward the election in 1955. In order to increase the people votes, the political parties make efforts to win the election in 1955. Those efforts are implemented in campaign to attract attention. Discourses scatter as an effort to ingratiate people. Four largest winning parties namely PNI, Masyumi, NU, and PKI, are also involved actively in campaign. Each of the, has good mapped approach and targets. In order to attract sympathy from people, the parties often have discourse fight. The discourse fight particularly occurs between PNI-Masyumi, PKIMasyumi. In Central Java, the discourses of parties and their fight also mark campaign process toward the voting day. Other parties consider Masyumi as a rival, so insistent attact comes to oppose Masyumi.
\end{abstract}

Keywords: 1955 election, political parties, campaign, Central Java

\begin{abstract}
ABSTRAK
Melalui kajian terhadap wacana kampanye dari berbagai dokumen, penelitian ini mencoba menguraikan konstelasi politik dan wacana kampanye di Jawa Tengah menjelang pemilu 1955. Dalam rangka meningkatkan perolehan suara rakyat, partai-partai politik melakukan upaya-upaya untuk memenangkan pemilihan umum tahun 1955. Upaya tersebut diimplementasikan dalam pelaksanaan kampanye untuk menarik perhatian. Wacana-wacana berhamburan sebagai upaya untuk mengambil hati rakyat. Empat besar partai pemenang pemilihan umum, yakni PNI, Masyumi, NU, dan PKI, juga terlibat secara aktif dalam kampanye. Masing-masing memiliki pendekatan dan sasaran yang telah dipetakan sedemikian rupa. Dalam rangka menarik simpati masyarakat tersebut, tak jarang partai-partai tersebut mengalami pertarungan wacana Pertarungan wacana terutama terjadi antara PNIMasyumi, PKI-Masyumi. Di Jawa Tengah, wacana-wacana partai dan pertarungannya juga mewarnai proses kampanye menjelang hari pemungutan suara. Partai-partai lain menganggap Masyumi sebagai rival, sehingga serangan bertubi-tubi datang menyerang Masyumi.
\end{abstract}

Kata kunci: pemilihan umum 1955, partai politik, kampanye, Jawa Tengah

\section{PENDAHULUAN}

Jawa Tengah dalam perpolitikan nasional adalah lumbung suara dalam pemilihan umum. Berdasarkan sensus penduduk tahun 2010, Jawa Tengah merupakan tiga terbesar provinsi dengan penduduk terbanyak. Jumlah penduduk Provinsi Jawa Tengah sebanyak 32.382.657 jiwa (Badan Pusat Statistik, 2010). Dari angka tersebut, jumlah penduduk yang telah memiliki hak pilih mencapai 22.716.205. Angka ini merupakan angka yang besar, karena dibandingkan dengan tahun 2009, jumlah pemilih di Indonesia adalah 
171.068.667 (Wahyudi, 2008). Sementara itu, pemilih yang menggunakan hak pilihnya adalah 104.095 .847 orang (Buletin Bawaslu, 2014: 10). Dengan demikian, dengan asumsi tersebut, Jawa Tengah menyumbangkan sekitar 13\% suara nasional. Pada pemilihan umum tahun 2014, jumlah suara sah untuk Pemilu Legislatif 2014 mencapai 124.972.491. Sementara itu, Jawa Tengah menyumbang 17.603.458 suara (Keputusan Komisi Pemilihan Umum Nomor: 411/Kpts/KPU/tahun 2014). Dengan demikian pada pemilihan legislatif 2014, Jawa Tengah menyumbang $14,08 \%$ suara nasional.

Besarnya kontribusi Jawa Tengah dalam pemilu tidak hanya pada pemilu 2009, tetapi dimulai dari pemilihan umum 1955. Jawa Tengah menjadi kajian dalam penelitian ini. Jawa Tengah yang dimaksud di sini adalah Jawa Tengah sebagai daerah pemilihan umum bukan sebagai wilayah administratif berdasarkan UU No 7 tahun 1953. Daerah Jawa Tengah sendiri meliputi Provinsi Jawa Tengah dan Daerah Istimewa Yogyakarta. Ditinjau dari skala nasional, hasil pemilihan umum di Jawa Tengah menyumbang sekitar $23,5 \%$ perolehan suara nasional pada pemilihan anggota parlemen dan menyumbang $23,9 \%$ dalam pemilihan anggota konstituante. Jumlah suara yang sah pada pemilihan umum di daerah Jawa Tengah mencapai 8.901.414 suara untuk pemilihan anggota parlemen dan 9.051.547 suara saat pemilihan anggota konstituante (Feith, 1971: 66). Ini menunjukkan peran penting Jawa Tengah terhadap suara-suara partai untuk kemenangan di tingkat nasioal. Bahkan suara PNI dan PKI tertinggi untuk tingkat nasional berasal dari Jawa Tengah dibandingkan perolehan di daerah-daerah pemilihan lainnya.

Dikaitkan dengan empat partai pemenang pemilihan umum, Jawa
Tengah pada pemilihan parlemen menyumbang kemenangan secara nasional sekitar 35,8\% untuk PNI, 11,5 $\%$ untuk Masyumi, 25,5\% untuk NU, dan sebagai penyumbang suara terbesar untuk PKI dengan perolehan suara $37,6 \%$ suara nasional. Pada pemilihan anggota konstituante, untuk tingkat nasional Jawa Tengah menyumbang suara $34,9 \%$ untuk PNI, $11,4 \%$ untuk Masyumi, 26\% untuk NU, dan 36,9\% untuk PKI. Dengan demikian, Jawa Tengah memiliki kontribusi terhadap kostelasi dan peta perpolitikan nasional pada tahun 1950-an.

Peran politik Jawa Tengah dalam pemilihan umum 1955 menjadi titik awal perpolitikan yang terjadi di saat ini. Hal ini karena ada kecenderungan untuk terjadinya kesinambungan ideologi dari dulu hingga kini. Oleh karena itu, penelitian ini secara spesifik mencari: (1) Bagaimana pelaksanaan pemilihan umum 1955 di Jawa Tengah; (2) Bagaimana peta persebaran politik pada pemilihan umum 1955 di Jawa Tengah; (3) Bagaimana persaingan kekuatan politik di Jawa Tengah pada pemilihan umum 1955;

\section{METODE PENELITIAN}

Sebagai penelitian historis, pada tahap awal, peneliti mencoba mencari sumber-sumber dalam menjawab permasalahan penelitian. Sumber-sumber terdiri atas sumber primer berupa sumber sezaman seperti arsip tentang kondisi masyarakat Jawa Tengah dari aspek sosial, ekonomi, dan pendidikan pada tahun 1950-an. Selain itu untuk mencari data tentang pelaksanaan pemilihan umum 1955, penulis mencoba untuk mendapatkan peraturan-peraturan yang mengatur pelaksanaan pemilihan umum yakni Maklumat Wakil Presiden Mohammad Hatta tanggal 3 November 
1945, yang berisi anjuran tentang pembentukan partai-partai politik. UUDS 1950, UU No 27 tahun 1948 tentang Pemilihan Umum, yang kemudian diubah dengan UU No. 12 tahun 1949 tentang Pemilihan Umum, serta UU No. 7 Tahun 1953 tentang Pemilihan Umum. Kemudian untuk mencari data tentang wacana dan berbagai pertarungan wacana penulis mencari dari surat kabar yang terbit menjelang pelaksanaan pemilihan umum, baik pemilihan umum untuk anggota parlemen atau untuk konstituante. Surat kabar yang dijadikan kajian terdiri atas surat kabar yang dikeluarkan oleh partai seperti Harian Ummat milik Masyumi, Suluh Indonesia milik PNI, Duta Masjarakat milik NU, dan Harian Rakjat dan Fikiran Rakjat milik PKI. Selain itu untuk menjaga objektivitas peneliti menggunakan pula surat kabar yang terbit secara independen yakni Berita Antara, Suara Merdeka dan Tangkas yang mengulas tentang pelaksanaan kampanye dan pemilihan umum 1955. Selain menggunakan sumber primer berupa arsip dan surat kabar yang terbit menjelang pemilihan umum, digunakan pula sumber-sumber sekunder dari buku dan penelitian yang terdahulu. Buku dan penelitian yang digunakan dalam penelitian ini antara lain buku tulisan Herbert Feit berjudul The Indonesian Election of 1955, The Decline of Constitutional Democracy in Indonesia. Selain itu digunakan pula penelitian-penelitian tentang pemilihan umum 1955.

Setelah sumber-sumber diperoleh peneliti melakukan upaya penilaian tentang keaslian sumber seperti mengamati hasil cetakan, jenis huruf, usia kertas dan sebagainya. Kemudian untuk mengetahui tingkat kredibilitas data peneliti membandingkan data yang satu dengan data yang lain, sehingga dapat diperoleh data dengan tingkat keterandalan yang baik.
Dalam menganalisis data-data hasil temuan, peneliti menggunakan pendekatan dari teori komunikasi politik. Hal ini karena peneliti mencoba untuk mencari bagaimana bentuk-bentuk komunikasi politik yang dilakukan oleh partai-partai politik menjelang pemilihan umum. Dengan bantuan dari teori komunikasi politik peneliti kemudian dapat menemukan fakta-fakta sejarah berkaitan dengan pertarungan wacana yang dilakukan oleh partai politik dalam kampanye pemilihan umum 1955.

\section{HASIL DAN PEMBAHASAN}

\section{Jawa Tengah Menjelang Pemilu 1955}

Provinsi Jawa Tengah adalah provinsi yang terpadat. Pada tahun 1952 tercatat kepadatan penduduk di Jawa Tengah yang meliputi Jawa Tengah dan Yogyakarta adalah 460 jiwa $/ \mathrm{km}^{2}$, sedangkan di Jawa Barat hanya 337 jiwa/ $\mathrm{km}^{2}$ dan Jawa Timur adalah 346 jiwa/ $\mathrm{km}^{2}$. Diperkirakan pada tahun 1955 sekitar 17 juta yang tersebar dalam 32 kabupaten/kota dan 6 karesidenan. Kenaikan jumlah penduduk yang sangat pesat dan kurang diimbangi adanya lapangan pekerjaan seperti perluasan areal pertanian menyebabkan sebagaian besar penduduk mengalami kesulitan dalam memenuhi kebutuhan hidupnya (Wicaksono, 2006: 48).

Secara umum, daerah kebudayaan Jawa, termasuk Jawa Tengah terbagi menjadi dua yaitu daerah pesisir dan daerah pedalaman. Masyarakat Jawa tinggal di desa yang merupakan daerah atau wilayah hukum yang sekaligus menjadi pusat pemerintahan tingkat daerah paling rendah. Pekerjaan utama masyarakat desa adalah bertani, baik itu mengolah tanah (untuk daerah pedalaman) atau mencari ikan (untuk daerah pesisir). Selain itu ada pula anggota 
masyarakat yang berdagang atau menjadi pegawai dan pekerjaan-pekerjaan lain.

Penduduk Jawa Tengah sebagian besar bermata pencaharian sebagai petani dan tinggal di pedesaan. Penduduk ini mengembangkan suatu pemikiran baku yang dapat digunakan sebagai suatu model untuk melakukan kegiatan yang dilakukan secara sadar atau tidak. Pemikiran tersebut juga merupakan suatu landasan untuk menjalankan kedudukan manusia dalam semesta ini. Termasuk dalam pemikiran itu yakni tempat manusia dalam masyarakat dan sekelilingnya yang juga merupakan pikiran-pikiran yang berhubungan dengan politik, kekuasaan, dan kekuatan. Politik sebagai suatu kumpulan konsep-konsep, aturan-aturan dan kegiatan-kegiatan akan dilihat sebagai bagian yang tidak terpisah dalam struktur sosial Jawa (Suparlan, 1977: 65).

Sistem kekerabatan orang Jawa berdasarkan prinsip keturunan bilateral (Kodiran, 1988: 337). Artinya masyarakat Jawa tidak menganut sistem keturunan beradasarkan bapaknya saja seperti yang ada pada masyarakat Batak atau manurut ibunya seperti yang ada pada masyarakat Minang. Hubungan sosial di desa sebagian besar berdasarkan sistem gotong royung yang mengenal berbagai bentuk tradisional. Sistem ini oleh orang desa dipahami sebagai perluasan hubungan kekerabatan yang memiliki pengaruh kuat atas seluruh kompleks hubungan intepersonal di seluruh desa (Magnis-Suseno, 1984: 18).

Dalam bidang kelas sosial, terdapat golongan-golongan sosial. Mereka membagi menjadi dua besar golongan yaitu golongan priyayi dan golongan wong cilik (Magnis-Suseno, 1984: 344). Golongan priyayi atau bendara merupakan golongan masyarakat yang diang- gap memiliki status tinggi seperti pejabat, orang kaya atau pegawai, sedangkan wong cilik adalah mereka yang memiliki status sebagai warga biasa yang terdiri dari para petani, pedagang, tukang dan para pekerja kasar lainnya. Ditinjau dari aspek keberagamaan masarakat Jawa, Clifford Geertz membagi lagi golongan wong cilik menjadi santri dan abangan. Dalam penentuan dan pemilihan partai politik, golongan-golongan ini sangat berpengaruh terhadap pilihan partai, seperti golongan priyayi lebih cenderung untuk memilih PNI, golongan santri memilih NU dan Masyumi, dan golongan abangan memilih PKI dan karena unsur Sukarno yang kental dalam PNI maka golongan abangan juga memilih PNI.

Sebagian besar masyarakat bermata pencaharian sebagai petani. Berdasarkan hal tersebut, mucul klasifikasi sosial di pedesaan didasarkan atas seberapa besar ia menguasai tanah. Menurut keadaan pertanian di Jawa, dapat dibedakan kelas-kelas sosial adalah tuan tanah, petani kaya, petani sedang, petani miskin, dan buruh tani (Fauzi, 1999: 124-125).

Pertama, tuan tanah adalah pemilik-pemilik tanah mulai dari sepuluh hektar ke atas. Mereka tidak mengerjakannya sendiri, tetapi menyewakanya pada pihak lain dengan sewa berupa uang atau hasil bumi secara bagi hasil. Kedua, petani kaya adalah orang yang memiliki tanah 5-10 hektar, tetapi ia ikut mengerjakan tanahnya sendiri. Meskipun demikian, mereka lebih senang mempekerjakan buruh tani daripada pihak lain dengan bagi hasil. Mereka hidup makmur dari eksploitasi tenaga buruh tani. Ketiga, petani sedang meliputi petani yang memiliki tanah 1-5 ha. Mereka mengerjakan tanahnya sendiri dengan alat-alat pertaniannya sendiri. Hasil perolehan dari usaha taninya mampu 
menghidupi keluarga. Keempat, petani miskin dicirikan dengan pemilikan tanah yang sempit (kurang dari satu hektar). Kehidupannya tidak cukup hanya dari hasil taninya. Karenanya, petani miskin mengerjakan tanah petani kaya atau tuan tanah dengan cara sebagai buruh atau bagi hasil. Kelima, buruh tani. Mereka pada umumnya tidak memiliki alat produksi sama sekali. Kehidupannya, bergantung sepenuhnya pada tenaga yang ia jual. Terutama pada petani kaya. Buruh tani merupakan satu kelas sosial yang merupakan kelas terbawah, yakni pekerja pertanian yang tak memiliki tanah. Tidak ada data makro yang diperoleh untuk bisa menggambarkan besarnya petani tak bertanah (buruh tani).

Di Jawa Tengah klasifikasi tersebut juga berlaku bagi masyarakat di daerah pedesaan yang berbasis pada pertanian. Berdasarkan data yang dihimpun oleh Kementrian Agraria pada 1957, di Jawa Tengah menunjukkan data sebagaimana pada tabel 1 .

Dari klasifikasi tersebut, dapat dilihat bahwa sebagian besar petani yang berada di Jawa Tengah adalah petani miskin dan buruh tani yang mencapai angka $83,41 \%$. Sementara itu jumlah petani sedang mencapai $16,14 \%$, sedangkan petani besar berada pada posisi kurang dari satu persen, yakni hanya mencapai $0,45 \%$. Angka ini menunjukkan bahwa kehidupan ekonomi masyarakat Jawa Tengah yang mayoritas adalah petani, sebagian besar masih berada pada klasifikasi masyarakat miskin.

Usaha pemerintah dalam menangani kebodohan mulai tampak. Anak-anak usia sekolah dipaksa untuk mengikuti sekolah. Sementara di kampung-kampung mulai diadakan kursus buta aksara. Sekolah-sekolah biasanya didirikan baru sampai tingkat kabupaten, pada tahun 1955 sekolah tersebut jumlahnya bertambah banyak yang telah menyebar sampai tingkat kecamatan (Wicaksono, 2006: 52). Namun demikian penduduk yang berada jauh di desa enggan mengikuti kegiatan sekolah dan lebih suka membantu orang tuanya sebagai petani atau peternak. Masuknya tokoh-tokoh politik dan pimpinan perjuangan sedikit banyak telah memicu perubahan sosial masyarakat di Jawa Tengah termasuk Yogyakarta.

Dalam masyarakat Jawa Tengah, sebagian orang beranggapan bahwa dengan masuk ke dalam sebuah partai, mereka bisa memperjuangkan statusnya atau paling tidak mempertahankannya. Para tuan tanah, majikan, pegawai negeri lebih condong untuk memilih

Tabel 1. Kepemilikan Tanah Pertanian di Jawa Tengah

\begin{tabular}{llll}
\hline No & Luas Tanah (Ha) & Jumlah Pemilik & Persentase \\
\hline 1 & $0-0.5$ & 956974 & 59.84 \\
2 & $0.6-1$ & 376875 & 23.57 \\
3 & $1,1-2$ & 187844 & 11.75 \\
4 & $2.1-5$ & 70227 & 4.39 \\
5 & $5.1-10$ & 6373 & 0.40 \\
6 & $10.1-20$ & 754 & 0.05 \\
7 & $>20$ & 137 & 0.01 \\
& Total & 1599184 & 100.00 \\
\hline
\end{tabular}

Sumber : Noer Fauzi. 1999. Petani dan Penguasa: Dinamika Perjalanan Politik Agraria Indonesia. Yogyakarta: Insis, KPA, dan Pustaka Pelajar. Hlm 126 
PNI dan Masyumi. Sementara itu buruh perani penggarap dan lainnya condong ke PKI. PKI menjadi pilihan karena mereka menjanjikan pembagian tanah, sehingga menyebabkan konflik tuan tanah dan PKI. Sementara itu di perkotaan banyak terjadi aktivitas politik dan penerbitan surat kabar-surat kabar (Wicaksono, 2006: 53).

Jawa Tengah boleh dibilang tergolong homogen dari segi etnis dan budayanya. Mayoritas penduduknya, 98 persen, bersuku Jawa dan dalam keseharian menggunakan bahasa Jawa. Jawa Tengah terbagi menjadi dua "mazhab" besar, nasionalis dan Islam. Pilihan politik nasionalis lebih banyak dianut penduduk wilayah pedalaman, sedangkan partai-partai yang mengusung ideologi Islam banyak mendapat tempat di pesisir utara. Namun, penguasaan pemilihnya lebih condong ke nasionalis. Segregasi pilihan politik ini ternyata bukan hanya bersifat struktural, tetapi juga bersifat kewilayahan. Pemilahan wilayah terjadi antara daerah pesisir utara dan pedalaman. Wilayah utara banyak dikuasai partai-partai Islam sedangkan pedalaman dikuasai oleh partai nasionalis (Syibly, 2009).

Pola kecenderungan politik ini relatif stabil, tidak berubah, dan sudah terjadi sejak Pemilu 1955. Ini menunjukkan seakan-akan pola politik aliran yang terjadi sejak pemilu pertama itu tidak berubah hingga kini. Politik aliran memang masih kuat, khususnya di Jawa. Pilihan politik penduduk di wilayah lebih banyak dipengaruhi faktor kepercayaan dan kecurigaan daripada faktor pilihan program- program yang ditawarkan partai politik (Syibly, 2009).

\section{Sistem Pelaksanaan Pemilihan Umum 1955}

Pemilihan Umum 1955 dianggap oleh banyak pakar satu-satunya pemi- lihan umum yang paling dekat dengan kriteria demokrasi. Pertama, jumlah dan pengorganisasian organisasi politik tidak dibatasi. Kedua, pelaksanaan pemilu benar-benar Luber (Langsung, Umum, Bebas, Rahasia. Ketiga, pluralisme kehidupan politik agak sama dengan era reformasi sekarang (King, 1998).

Pemilu 1955 adalah wujud dari keinginan masyarakat Indonesia untuk menerapkan kehidupan yang demokratis. Rencana untuk mengadakan pemilu nasional sebenarnya sudah diumumkan sejak Oktober 1945. Satu bulan kemudian, sebagai persiapan diadakannya pemilu nasional tersebut, dikeluarkanlah Maklumat Pemerintah tentang pembentukan partai-partai politik tanggal 3 November 1945 yang ditandatangani oleh Wakil Presiden (Poesponegoro \& Notosusanto, 1984: 622; Sekretariat Negara, 1975: 56).

Setelah itu kemudian disusun UU No. UU No 27 tahun 1948 tentang Pemilu, yang kemudian diubah dengan UU No. 12 tahun 1949 tentang Pemilu. Di dalam UU No 12/1949 diamanatkan bahwa pemilihan umum yang akan dilakukan adalah bertingkat (tidak langsung). Sifat pemilihan tidak langsung ini didasarkan pada alasan bahwa mayoritas warganegara Indonesia pada waktu itu masih buta huruf, sehingga kalau pemilihannya langsung dikhawatirkan akan banyak terjadi distorsi.

Kemudian pada paruh kedua tahun 1950, ketika Mohammad Natsir dari Masyumi menjadi Perdana Menteri, pemerintah memutuskan untuk menjadikan pemilu sebagai program kabinetnya (Feith, 1962). Sejak itu pembahasan UU Pemilu mulai dilakukan lagi, yang dilakukan oleh Panitia Sahardjo dari Kantor Panitia Pemilihan Pusat sebelum kemudian dilanjutkan ke parlemen. Pada waktu itu Indonesia kembali menjadi negara kesatuan, setelah sejak 
1949 menjadi negara serikat dengan nama Republik Indonesia Serikat (RIS). Setelah Kabinet Natsir jatuh 6 bulan kemudian, pembahasan RUU Pemilu dilanjutkan oleh pemerintahan Sukiman Wirjosandjojo, juga dari Masyumi. Pemerintah ketika itu berupaya menyelenggarakan pemilu karena pasal 57 UUDS 1950 menyatakan bahwa anggota DPR dipilih oleh rakyat melalui pemilihan umum. Tetapi pemerintah Sukiman juga tidak berhasil menuntaskan pembahasan undang-undang pemilu tersebut. Selanjutnya UU ini baru selesai dibahas oleh parlemen pada masa pemerintahan Wilopo dari PNI pada tahun 1953. Maka lahirlah UU No. 7 Tahun 1953 tentang Pemilu. UU inilah yang menjadi payung hukum Pemilu 1955 yang diselenggarakan secara langsung, umum, bebas dan rahasia. Dengan demikian UU No. 27 Tahun 1948 tentang Pemilu yang diubah dengan UU No. 12 tahun 1949 yang mengadopsi pemilihan bertingkat (tidak langsung) bagi anggota DPR tidak berlaku lagi.

Dalam pemilihan umum tahun 1955, Indonesia menganut sistem multipartai. Sistem multipartai yang disandingkan dengan sistem pemerintahan parlementer, mempunyai kecenderungan untuk menitikberatkan kekuasaan pada badan legislatif sehingga peranan badan eksekutif sering lemah dan ragu-ragu. Hal ini disebabkan tidak ada satu partai yang cukup kuat untuk membentuk suatu pemerintahan sendiri, sehingga terpaksa membentuk koalisi dengan partai-partai lain. Dalam keadaan semacam ini partai yang tidak berkoalisi harus selalu mengadakan musyawarah dan kompromi dengan partai-partai lainnya dan menghadapi kemungkinan bahwa sewaktu-waktu dukungan dari partai koalisi lainnya dapat ditarik kembali (Budiardjo, 1977: 169-170).

Maurice Duverger (dalam
Budiardjo, 1977: 170) menjelaskan bahwa pola multipartai umumnya diperkuat oleh sistem pemilihan perwakilan berimbang (proportional representation) yang memberi kesempatan luas bagi pertumbuhan partai-partai dan golongan kecil. Melalui sistem perwakilan berimbang partai-partai kecil dapat menarik keuntungan dari ketentuan bahwa kelebihan suara yang diperolehnya di suatu daerah pemilihan dapat ditarik ke daerah pemilihan lain untuk menggenapkan jumlah suara yang diperlukan guna memenangkan satu kursi (Feith, 1971:3).

Dalam pemilihan umum tahun 1955, digunakan sistem pemilihan proporsional. Sistem ini dimaksudkan untuk menghilangkan beberapa kelemahan dari sistem distrik. Gagasan pokok ialah bahwa jumlah kursi yang diperoleh oleh suatu golongan atau partai adalah sesuai dengan jumlah suara yang diperolehnya. Untuk keperluan ini ditentukan suatu perimbangan, misalnya 1:400.000 yang berarti bahwa sejumlah pemilih tertentu (dalam hal ini 400.000 pemilih) mempunyai satu wakil dalam dewan perwakilan rakyat. Jumlah total anggota dewan perwakilan rakyat ditentukan atas dasar perimbangan (1:400.000) itu. Negara dianggap sebagai satu daerah pemilihan yang besar, akan tetapi untuk keperluan teknisadministratif dibagi dalam beberapa daerah pemilihan yang besar (yang lebih besar dari distrik dalam sistem distrik), di mana setiap daerah pemilihan memiliki sejumlah wakil sesuai dengan banyaknya pendduk dalam daerah pemilihan itu. Jumlah wakil dalam setiap daerah pemilihan ditentukan oleh jumlah pemilih dalam daerah pemilihan itu, dibagi dengan 400.000 (Budiardjo, 1977: 177-180).

Dalam sistem ini setiap suara dihitung, dalam arti bahwa suara lebih yang diperoleh oleh suatu partai atau go- 
longan dalam suatu daerah pemilihan dapat ditambahkan pada jumlah suara yang diterma oleh partai atau golongan itu dalam pemilihan lain, untuk menggenapkan jumlah suara yang diperlukan guna memperoleh kursi tambahan. Sistem perwakilan berimbang sering dikombinasikan dengan beberapa prosedur antara lain dengan sistem daftar (list system). Dalam sistem daftar setiap partai atau golongan mengajukan satu daftar calon dan si pemilih satu partai dengan semua calon yang diajukan oleh partai itu bermacam-macam kursi yang sedang direbutkan. Sistem ini memiliki satu keuntungan besar, yakni bahwa dia bersifat representatif dalam arti bahwa setiap surat suara turut diperhitungkan dan praktis tidak ada suara yang hilang. Golongangolongan bagaimana kecilpun dapat mendapatkan wakilnya dalam badan perwakilan rakya. Masyarakat yang heterogen sifatnya, umumya lebih tertarik pada sistem ini karena dianggap lebih menguntungkan masing-masing golongan (Budiardjo, 1977: 177-180).

Secara spesifik, sistem proporsional yang digunakan adalah Sistem Perwakilan Berimbang dengan sistem daftar terbuka (Open List System). Dengan sistem ini para pemilih tidak hanya memilih partai tetapi juga memilih calon yang dikehendaki. Pemilih disamping mencoblos gambar juga mencoblos nama calon yang dikehendaki. Bergantung pada berapa kursi yang disediakan untuk distrik tersebut. Kelebihan sistem ini adalah para pemilih yang menentukan calon, bukan pemimpin partai yang lebih menentukan calon mana yang di kehendaki dan calon mana yang ditolak (Friyanti, 2005: 33).

Dalam pemilihan umum 1955, berdasarkan UU No. 7 tahun 1953 tentang Pemilihan Anggota Konstituante dan Anggota Dewan Perwakilan Rakyat pasal 15 ayat 1 dinyatakan pemilihan umum untuk terbagi atas beberapa daerah pemilihan, yakni (1) Jawa Timur, (2) Jawa Tengah, (3) Jawa Barat, (4) Jakarta Raya, (5) Sumatera Selatan, (6) Sumatera Tengah, (7) Sumatera Utara, (8) Kalimantan Barat, (9) Kalimantan Selatan, (10) Kalimantan Timur, (11) Sulawesi Utara-Tengah (12) Sulawesi Tenggara-Selatan, (13) Maluku, (14) Sunda-Kecil Timur, (15) Sunda-Kecil Barat, dan (16) Irian Barat.

Anggota Konstituante dan anggota Dewan Perwakilan Rakyat dipilih oleh warganegara Indonesia, yang dalam tahun pemilihan berumur genap 18 tahun atau yang sudah kawin lebih dahulu, termasuk golongan militer dan polisi. Namun demikian, dalam UU no 7 tahun 1953 juga dijelaskan bahwa seorang tidak diperkenankan menjalankan hak-pilih, apabila ia (1) tidak terdaftar dalam daftar-pemilih, (2) dengan putusan pengadilan, yang tidak dapat diubah lagi, sedang dalam keadaan dipecat dari hak-pilih, (3) dengan putusan pengadilan, yang tidak dapat diubah lagi, sedang menjalani hukuman penjara atau kurungan, termasuk di dalamnya kurungan pengganti, dan (5) nyata-nyata terganggu ingatannya. Pemilihan umum pertama yang dilaksanakan di seluruh tanah air kecuali Irian Barat memperebutkan 257 kursi DPR dengan jumlah pemilih sebanyak 43.104.464 orang (Feith, 1971).

Persiapan untuk pemilihan umum telah diadakan oleh Kabinet Ali Sastroamijoyo I (31 Juli 1953-12 Agustus 1955). Sebelumnya setelah pengesahan undang-undang tentang pemilu, dibentuklah Panitia Pemilihan Indonesia (PPI) melalui keputusan Presiden Republik Indonesia tertanggal 7 November 1953, PPI dilantik dan diangkat sumpahnya oleh kepala negara pada tanggal 28 November 1953. Dilanjutkan dengan serah terima dengan Kantor Pemilihan Pusat 
pada tanggal 3 Desember 1953. S Hadikusumo dari PNI terpilih sebagai ketua PPI. Anggota-anggoanya dipilih dari berbagai partai, yakni NU, PSII, PRI, PRN, Partai Buruh, BTI, Perti, Parkindo (Feith, 1962: 384).

Hal-hal yang dipersiapkan antara lain membentuk panitia pemilihan umum, baik untuk pusat maupun untuk daerah, menetapkan daerah pemilihan dan daerah pemungutan suara. Pada tanggal 16 April 1955 diumumkan bahwa pemilihan umum akan dilaksanakan pada tanggal 29 September 1955 untuk memilih anggota DPR dan tanggal 15 Desember 1955 untuk memilih anggota konstituante. Dengan adanya pengumuman tersebut maka partai politik mulai berkampanye untuk menarik simpati rakyat (Feith, 1962: 46). Namun demikian, pada pemilihan untuk parlemen direncanakan serempak pada tanggal 29 September, tetap ada beberapa wilayah yang tidak dapat menjalankan pada hari tersebut. Untuk mengatasi hal itu, maka diberikan putusan bahwa daerah yang tidak sanggup melaksanakan pemilihan pada tanggal 29 September 1955 mendapatkan dispensasi selama dua bulan sampai tanggal 29 November untuk melaksanakan pemilihan umum. Daerah-daerah yang masih belum siap antara lain Aceh Barat, Aceh Timur, Aceh Utara, Riau, Bengkalis, Batanghari, Sanggau, Kapuas Hulu, Barito, Kotawaringin, Kotabaru, Bulungan, Poso, Donggala, Manggarai, Maluku Utara, Maluku Tenggara, dan lain-lain (Suara Merdeka, 9 September 1955).

Dalam rangka menghadapi pelaksanaan pemilihan umum, Jawa Tengah melalui ketua Panitia Pemilihan, Rustamadji, menyatakan bahwa Jawa Tengah telah siap untuk menyelenggarakan pemilihan umum untuk parlemen tanggal 29 September 1955. Lebih lanjut lagi dinyatakan bahwa pada pemilihan umum 1955, jumlah penduduk
Jawa Tengah adalah 17.602.101 dan yang terdaftar sebagai pemilih adalah 10.120.962. Di Jawa Tengah terdapat sekitar 16.209 tempat pemungutan suara (Suara Merdeka, 10 September 1955).

Peserta pemilihan umum dari kalangan Partai atau organisasi adalah 28 untuk parlemen, dan 34 untuk majelis konstituante. Peserta pemilihan umum 1955 dapat digolongkan berdasarkan ideologinya (Pabotinggi, 1998: 43). Pertama, partai politik yang beraliran nasionalis yaitu partai politik peserta pemilihan umum 1955 yang beraliran nasionalis antara lain Partai Nasional Indonesia (PNI), Ikatan Pendukung Kemerdekaan Indonesia (IPKI), Gerakan Pembela Pancasila, Partai Rakyat Nasional, Persatuan Pegawai Polisi Republik Indonesia (PPPRI), Partai Buruh, Partai Rakyat Indonesia, PRIM, Partai R. Soedjono Prawirosoedarso, Partai Indonesia Raya Wongsonegoro, Partai Indonesia Raya Hazairin, Persatuan Rakyat Marhaen Indonesia (PERMAI), Partai Persatuan Daya.

Kedua, partai politik yang beraliran Islam. Partai politik peserta pemilihan umum 1955 yang beraliran Islam antara lain Masyumi, Nahdlatul Ulama (NU), Partai Serikat Islam Indonesia (PSII), Partai Islam Perti, AKUI, Partai Politik Tharikat Islam (PPTI). Ketiga, Partai politik yang beraliran komunis. Partai peserta pemilihan umum yang beraliran komunis antara lain Partai Komunis Indonesia (PKI) dan ACOMA.

Keempat, partai politik yang beraliran sosialis. Partai yang beraliran sosialis antara lain Partai Sosialis Indonesia (PSI), Partai Murba, Partai Rakyat Desa dan Baperki. Kelima, partai yang beraliran Kristen/Nasrani, yakni partai peserta pemilihan umum yang beraliran Kristen/Nasrani antara lain Partai Kristen Indonesia (Parkindo), dan Partai Katolik.

Dalam pemilihan umum total 
pengeluaran sekitar 550 juta, padahal pada mulanya ditaksir hanya sekitar 300 juta (Tangkas, 29 Agustus 1955). Di Jawa Tengah sendiri, sampai tiga minggu sebelum pelaksanaan pemilihan umum, total pengeluaran telah mencapai 25 juta. Uang tersebut digunakan untuk distribusi alat-alat, biaya bangunan yang mencapai 4.200.000, ongkosongkos pelatihan senilai 462.000 , dan sebagainya (Suara Merdeka, 10 Agustus 1955).

\section{Kampanye Pemilu 1955 di Jawa Tengah: Wacana 4 Partai Terbesar}

Partai Nasional Indonesia (PNI) sebelum pelaksanaan pemilihan umum dianggap merupakan partai terbesar kedua. Selama revolusi partai ini berkembang luas berlandaskan dukungan terutama dari elit administratif dan dari abangan kaum tani pada Jawa dan mengandung satu jangkauan luas dengan sudut pandang ideologis. PNI memiliki padangan utama yakni Marhaen atau "nasionalisme proletar" (Cribb \& Kahin, 2004: 324-325).

Wacana utama yang dimunculkan oleh PNI pada dasarnya adalah marhaenisme. Ideologi ini lahir pada tanggal 4 Juli 1927 (Suluh Indonesia, 4 Juli 1955). Marhaenisme merupakan ideologi yang tumbuh subur di Indonesia. Pada dasarnya, marhaenisme menekankan pada aspek kemandirian dalam berbagai aspek yang diawali dalam hal pangan. Marhaenisme menjadi core frame yang melandasi berbagai wacana yang kemudian dikembangkannya. Bahkan karena begitu kuatnya marhaen dalam PNI, di lambang PNI tertulis tulisan "FRONT MARHAENIS". Istilah ini merupakan konsep diadopsi oleh Sukarno untuk melihat bagaimana realitas sejumlah besar dari Indonesia, terutama petani mandiri, yang walaupun sangat miskin dan ditekan oleh kapitalisme kolonial, adalah pemilik yang mandiri dan tidak termasuk orang yang proletar (Cribb \& Kahin, 2004: 259).

Dari core frame tentang marhaenisme yang dikampanyekan dalam berbagai programnya, ada beberapa wacana lain yang juga dikampanyekan oleh PNI. Selain mengangkat tentang marhaenisme, PNI juga mengampanyekan bahwa PNI memiliki kedekatan secara kultural dengan Sukarno sebagai pencetus paham marhaenisme. Dalam salah satu terbitannya bahkan mengangkat judul besar yang bertuliskan "Bung Karno udah Pasti Tusuk Tanda Gambar PNI". Hal ini dinyatakan oleh "S" bahwa dalam pemilihan umum yang akan datang Bung Karno sudah pasti memilih tanda gambar PNI (Suluh Indonesia, 15 September 1955). Wacana tentang Bung Karno sebagai kader dari PNI merupakan sebuah wacana yang sangat penting dan efektif untuk menjaring suara dari kalangan masyarakat bawah, terutama di Jawa Tengah yang sebagian masyarakatnya adalah masyarakat yang hidup di kawasan pedalaman dan cenderung lebih bersifat konformis dan agraris daripada masyarakat pesisir yang dinamis. Ini pulalah yang dimungkinkan menjadi faktor penentu kemenangan PNI yang sangat signifikan di Jawa Tengah.

Partai komunis Indonesia (PKI) yang dihancurkan namun tidak dilarang pada tahun 1948, hampir siap muncul kembali secara paling menakjubkan dalam sejarahnya yang berganti-ganti. Pada awal perkembangannya setelah peristiwa Madiun, PKI masih merupakan partai yang kecil akan tetapi sangat disiplin dan efektif. Aktivitasnya melingkupi kalangan proletariat di kotakota maupun di kalangan buruh-buruh baik di kota maupun yang bekerja di bidang pertanian. Kalangan petani inilah yang banyak mendapat perhatian 
dari PKI (Feith, 1971:9).

Dari gambaran tersebut, ideologi marxisme menjadi landasan PKI, sehingga core frame yang diangkat adalah tentang masalah rakyat. Di banyak kampanye yang dilakukan kata "rakyat" menjadi satu faktor yang melingkupi wacana kampanyenya dan janji serta program yang ditawarkan. Hal ini jelas tampak dari nama surat kabar yang digunakan sebagai alat gerak partai, seperti Harian Rakjat dan Fikiran Rakjat.

Menjelang pemilihan umum, PKI semakin aktif dalam melakukan kampanyenya. Bagi PKI pemilu merupakan sebuah konkretisasi dari gerakan rakyat atau revolusi nasional pada waktu itu. Pemilu adalan gerakan politik, gerakan rakyat yang luas untuk memperjuangkan nasibnya sendiri (Harian Rakjat, 15 Januari 1955).

Wacana yang dikeluarkan oleh PKI juga dengan menunjukkan kebesaran partai dengan menonjolkan sejarahnya. Pada Harian Rakjat tanggal 23 mei terdapat pidato aidit tentang sejarah PKI yang menonjolkan perannya dalam memperjuangkan kaum buruh (Harian Rakjat, 23 Mei 1955).

Untuk menarik simpati di berbagai lapisan masyarakat, seperti pemuda, ibu-ibu, seni dan sebagainya dengan menerbitkan tulisan-tulisan khusus "... menangkan PKI untuk hakhak dan tingkat hidup pemuda yang lebih baik, pemuda harus memberikan suaranya dalam pemilihan ini kepada wakil-wakil yang akan sanggung memperjuangkan tuntutan mereka, kebebasan berpolitik, berorganisasi, dan beragama bagi pemuda, perbaikan upah, kenaikan gaji, perluasan lapangan kerja, berolah raga, kesenian, pembasmian di rii dan berbagai unsur yang melakukan sabotase, korup, dan kolonial di kalangan aparat negara" (Harian Rakjat, 23 Mei 1955).

Partai dengan perolehan tertinggi ketiga di Jawa Tengah adalah NU. Dalam rapat NU pada tanggal 5 April 1952 di Surabaya diputuskan untuk keluar dari Masyumi. Jika partai lain khususnya partai-partai besar mempunyai waktu yang cukup lama berdiri sebagai partai politik, karena itu lebih cukup waktu dan kesempatan mengapresiasikan politik dan pengaruh kepada rakyat, maka NU hanya mempunyai waktu sekitar tiga tahun saja (PCINU Mesir, 2010). Dalam waktu tiga tahun inilah, NU mulai mengintensifkan kampanye untuk meraih suara rakyat. NU merupakan partai dengan basis Islam tradisional dengan massa yang berasal dari kalangan santri pedesaan. Inilah yang menjadi core frame dalam wacanawacana NU pada saat kampanye, yakni ideologi NU tentang Islam yang menganut paham ahlussunah wal jamaah. NU sebagai organisasi Islam tradisional tapi moderat memiliki pandangan tentang Islam keindonesiaan. Inilah wacanawacana yang dikembangkan dan menjadi landasan dalam wacana-wacana lainnya. Ini terutama sangat tampak dari jargon yang dimiliki oleh Duta Masyarakat sebagai surat kabar underbouw NU yang menyebutkan "pendukung cita-cita kerja sama Islamnasional" (Duta Masyarakat, 19 September 1955).

Pendekatan agama menjadi satu sarana yang dilakukan oleh NU untuk menjaring suara pada pemilihan umum 1955. Pesantrn-pesantren menjadi tempat yang efektif untuk menyebarluaskan pengaruh partai. Hal ini tampak dengan pemanfaatan pesantren sebagai basis masa bagi NU, seperti ketika dilakukan konferensi alim ulama seluruh Jawa Tengah yang dilaksanakan di pondok Watucongol, Muntilan yang dihadiri lebih kurang 150 alim ulama, 100 peninjau dan kurang lebih 10.000 orang (Duta Masyarakat, 19 September 1955).

Dengan core frame Islam yang 
keindonesiaan, partai NU didirikan untuk memperjuangkan pelaksanaan masyarakat Islam dan untuk melindungi masyarakat Islam dan masyarakat lain pada umumnya. Sebagai partai yang berlandaskan agama, maka kampanye yang dilakukan tidak "segarang" kampanye yang dilakukan oleh partai sekuler.

Masyumi merupakan partai dengan perolehan suara terkecil di antara empat partai besar pemenang pemilu di Jawa Tengah. Masyumi mewakili kepentingan-kepentingan Islam dan dianggap merupakan partai yang terbesar di negara ini, walaupun sampai terselenggarakannya pemilihan umum, hal ini hanya dapat menjadi anggapan belaka. Partai ini tidak terorganisasi secara teratur, dan mengalami perpecahan utama di dalamnya antara para pemimpin Islam ortodoks dan modernis (Ricklefs, 2005: 477).

Core frame yang digunakan oleh masyumi dalam menyampaikan wacana-wacana kampanyenya adalah Islam. Islam yang dimaksud di sini adalah Islam yang bersifat modernis. Hal ini karena basis massa dari Masyumi adalah kalangan santri perkotaan. Namun demikian, isu ini justru digunakan lawan-lawan politik dari Masyumi untuk menjatuhkan Masyumi bahwa Masyumi merupakan partai yang menghendaki perubahan menjadi negara Islam. Oleh karena itu, dalam tiap melontarkan wacana dalam kampanye Masyumi juga selalu mengaitkan bahwa perjuangan Masyumi juga untuk tegaknya proklamasi.

Oleh karena Islam adalah sebagai core frame dalam tiap wacana yang dikemukakan, maka menjelang pamilihan umum Masyumi Jawa Tengah mengeluarkan fatwa yang ditujukan kepada seluruh umat Islam, khususnya keluarga masyumi untuk melakukan amalan menuju taqarrub ilallah. Seperti anjuran untuk solat malam, membaca doa-doa tertentu, memperbanyak membaca Quran, berpuasa sunah, terutama pada Senin tanggal 26 September 1955 dan diikuti dengan gerakan sodaqoh, meperkuat ukhuwah islamiyyah dengan jalan menjalin silaturaim dan tolong menolong, waspada terhadap golongan yang tidak mengenal tuhan, menjalin persatuan, dan membulatkan tekad (Suara Merdeka, 24 September 1955).

Kampanye yang secara massif dilakukan oleh partai-partai politik telah menetapkan PNI sebagai partai dengan suara terbanyak, kemudian disusul oleh PKI, NU, dan Masyumi. Hasil pemilu untuk parlemen di Jawa Tengah terdapat pada tabel 2 .

\section{Pertarungan Politik Kampanye Pada Pemilu 1955}

Kehidupan partai politik menjelang diselenggarakannya pemilu banyak diwarnai oleh pertentangan politik, terutama oleh partai-partai besar. Partai politik berupaya mencari dukungan massa dengan menyelenggarakan kampanye. Metode dan teknik kampanye yang digunakan oleh partaipartai politik peserta pemilu sangat beragam. Pertemuan-pertemuan diselenggarakan di semua tingkat, di alun-alun kota atau balai desa dengan para pembicara dari Jakarta atau tokoh partai setempat. Pemutaran film, perayaan hari besar agama, perayaan ulang tahun atau pawai, tanda-tanda gambar partai di berbagai tempat, dan lain-lain. Bagi sebagian besar partai semua ini merupakan upaya untuk menambah jumlah anggota tapi bagi sebagian lagi kegiatan ini merupakan kegiatan sambil lalu dengan menyebarkan surat kabar serta pamphlet partai (Feith, 1971: 31). Kampanye pemilu dengan cara menyelenggarakan rapat-rapat raksasa antara keti- 
ka partai itu berjalan seru, mereka saling menvela, kadang-kadang dengan nada sangat tajam. Mereka tak peduli apakah hal-hal tersebut ditujukan kepada seseorang yang sedang menjabat menteri, anggota parlemen, atau orang biasa (Moedjanto, 1988: 91).

Pada bulan april 1953, undangundang tentang pemilihan umum akhirnya disahkan. Untuk pertama kalinya, para politisi Jakarta kini mulai bekerja membangun dukungan massa yang akan memberikan suara. Dalam usaha mencari dukungan rakyat itu, mereka menggunakan banyak daya tarik ideologis yang meningkatkan ketegangan masyarakat-masyarakat di desa-desa. Pada akhirnya partai Islam di tingkat bawah menghendaki sebuah negara yang didasarkan pada hukum Islam. Partai-partai sekuler terutama PNI dan PKI berusaha mengaitkan Masyumi dengan Darul Islam dan mengubah Pancasila lebih sebagai slogan anti-Islam daripada falsafah pengayoman seperti yang dikehendaki Sukarno. Selama lebih dari dua tahun, kekacauan politik dan kekerasan meningkat,dan diharapkan oleh banyak orang bahwa pemulihan-pemulihan tersebut akan menghasilkan suatu struktur politik yang kokoh untuk masa mendatang (Ricklefs, 2005: 488).

PNI, Masyumi, NU, dan PKI adalah rival yang bersaing secara ketat, sehingga tidak jarang terjadi brebagai gesekan antara keempat partai tersebut. PNI terang-terangan menolak Darul Islam. Begitu pula antara Masyumi dan NU dengan nasionalis atau komunis. Semuanya diungkapkan secara gamblang, termasuk dalam rapat akbar untuk menggaet pemilih (Tempo 13/XXVIII 31 Mei 1999).

Petarungan wacana yang tajam terjadi terutama antara PNI-Masyumi, PKI-Masyumi, dan PNI-PKI. Sementara itu antara partai-partai Islam per- tarungan wacana tidak terlalu tajam karena di antara partai-partai Islam dilakukan kesepakatan untuk menjaga ukhuwah islamiyyah. Pada tanggal 15 Juni pimpinan PSII, NU, Masyumi, dan Perti menginstruksikan kepada keluarga partai masing-masing untuk menjaga dengan sungguh-sungguh agar perbedaan paham di lapangan politik jangan sampai merusak ukhuwah islamiyyah yang dituangkan dalam satu pernyataan untuk tidak saling menyerang dalam menghadapi pemilihan umum tahun 1955 (Suara Merdeka, 16 Juni 1955).

Namun demikian, walaupun terdapat pernyataan tidak saling serang bukan berarti menghilangkan pertarungan wacana. Di antara partaipartai Islam pertarungan wacana tersebut terjadi, seperti ketika harian Duta Masjarakat mengeluarkan berita tentang Kiai Asnawi dari NU yang namanya dicatut menjadi bagian dari partai Masyumi (Duta Masjarakat, 2 September 1955). Walaupun telah ada kesepakatan di beberapa kawasan ternyata kesepakatan itu tidak berjalan, sehingga muncul saling serang dan bertahan. NU mengkritik bahwa ada golongan yang pro-Islam ternyata anti ulama dengan menjatuhkan nama beberapa ulama. Hal ini diungkapkan oleh Idam Chalid dalam pidatonya beberapa hari menjelang pemilihan legislatif (Duta Masjarakat, 19 September 1955).

Dari pertarungan wacana yang terjadi, tampaknya Masyumi menjadi partai yang mendapatkan berbagai serang bertubi-tubi dari rival politiknya, terutama dari PNI. PKI juga turut menjadi bagian yang melakukan kritik terhadap Masyumi. Dalam menjalankan perjuangannya, PKI dikenal sebagai sebuah partai yang selalu mengambil jalan dan cara apapun, asal tujuan tercapai. Tak terkecuali dalam menghadapi lawan-lawan politiknya menjelang pemilihan umum PKI terus mencela se- 
bagaian besar partai-partai nasionalis, dan keagamaan sebagai partai-partai kaum imperialis. Harian Rakjat selalu menulis segala macam tindakan masyumi yang dianggap salah, seperti Masyumi tidak anti-Belanda, tidak anti kolonialisme, tidak anti gerombolan subversif seperti gerakan DI/TII. PKI juga menuduh Masyumi menyalahgunakan agama, dan masyumi berniat mengganti RI dengan bentuk negara lain yang dinamakan Darul Islam. Dalam sebuah kampanyenya, secara terang-terangan bahkan ditulis "cegah kemenangan Masyumi dalam pemilihan umum nanti dan pilihlah partai yang membela kepentingan nasional: PKI dan partai-partai d e mokrasi lainnya." (Khotimah, 2003: 61). Pernyataan PKI ini juga terdapat pada harian Fikiran Rakjat yang menyatakan secara terang-terangan untuk mengalahkan Masyumi dan PSI karena dianggap sebagai partai penguasa yang telah mengakibatkan krisis yang memunculkan penderitaan rakyat (Fikiran Rakjat, 28 September 1955). Menghadapi wacana tersebut, Masyumi kemudian melakukan counter seperti dengan menyatakan bahayanya perkembangan komunisme dengan menunjukkan data kesejarahan (Suara Ummat, 3 Oktober 1955). Masyumi juga melakukan upaya counter dengan menyebutkan bahwa PKI telah melakukan upaya pemecahbelahan antara NU dan Masyumi (Suara Ummat, 3 Desember 1955).

Antara PNI dan PKI juga terdapat pertarungan yakni ketika muncul pernyataan yang menyatakan bahwa PNI adalah musuh besar PKI. Pernyataan ini diungkapkan oleh Tony Wen yang menyatakan bahwa sosialisme (marhaenisme) yang dianut oleh PNI berbeda dengan sosialisme yang dianut oleh PKI, di mana sosialisme PKI mengarah pada internasionalisme yang tidak mencintai tanah air (Suara Ummat,
30 November 1955).

Perang wacana yang paling panas adalah antara PNI dan Masyumi. Pertarungan antara dua kekuatan terkuat ini makin memanas ketikaterjadi perubahan dari kabinet Ali Sasatroamidjojo yang berasal dari PNI ke Burhanudin Harahap dari Masyumi, di mana tidak satupun orang PNI dimasukkan dalam kabinet. Saling serang dan bertahan dilakukan oleh kedua partai tersebut. PNI selalu melakukan upaya penyerangan terhadap kinerja kabinet Burhanudin Harahap. Selain itu dalam Suluh Indonesia disebutkan bahwa Masyumi mempropagandakan bahwa perintahperintah dari pamong desa dari PNI tidak usah ditaati karena orang yang berkuasa adalah orang Masyumi (Suluh Indonesia, 7 September 1955). Selain itu ada pula wacana tentang pencatutan Bung Karno oleh orang-orang Masyumi (Suluh Indonesia, 5 September 1955). Hal yang paling sering diangkat dalam wacana-wacana untuk menyerang Masyumi adalah wacana tentang Masyumi akan mengubah ideologi Indonesia menjadi negara Islam. Hal ini tampak pada beberapa terbitan dari Suluh Indonesia (Suluh Indonesia, 20 dan 26 September 1955).

\section{SIMPULAN}

Dalam rangka meningkatkan perolehan suara rakyat, partai-partai politik melakukan upaya-upaya untuk memenangkan pemilihan umum tahun 1955. Upaya tersebut diimplementasikan dalam pelaksanaan kampanye untuk menarik perhatian. Wacana-wacana berhamburan sebagai upaya untuk mengambil hati rakyat. Empat besar partai pemenang pemilihan umum, yakni PNI, Masyumi, NU, dan PKI, juga terlibat secara aktif dalam kampanye. Masing-masing memiliki pendekatan 
dan sasaran yang telah dipetakan sedemikian rupa. Wacana utama yang diangkat oleh PNI adalah marhaenisme yang menekankan pada kemandirian. Sementara itu Masyumi mengangkat wacana utama tentang partai Islam yang membawa kebenaran Tuhan. Sementara itu NU yang juga partai Islam membawa konsep tentang Islam yang keindonesiaan. Dan PKI membawa wacana tentang kerakyatan dalam bingkai marxisme.

Dalam rangka menarik simpati masyarakat tersebut, tak jarang partaipartai tersebut mengalami pertarungan wacana. Hal ini terjadi pula pada partai empat besar pemenang pemilu 1955. Pertarungan wacana terutama terjadi antara PNI-Masyumi, PKI-Masyumi. Di Jawa Tengah, wacana-wacana partai dan pertarungannya juga mewarnai proses kampanye menjelang hari pemungutan suara. Partai-partai lain menganggap Masyumi sebagai rival, sehingga serangan bertubi-tubi datang menyerang Masyumi.

\section{DAFTAR PUSTAKA}

Antara , 25 Desember 1955

Badan Pusat Statistik. 2010. Sensus Penduduk 2010. Dalam http://sp2010.bps.go.id/ (diakses 14 Januari 2015).

Budiardjo, Miriam. 1977. Dasar-Dasar Ilmu Politik. Jakarta: Gramedia.

Buletin Bawaslu, 2 Februari 2014.

Cribb, Robert \& Audrey Kahin. 2004. Historical dictionary of Indonesia. Maryland: The Scarecrow Press, Inc. Duta Masjarakat, 19 September 1955

Duta Masjarakat, 2 September 1955

Duta Masjarakat, 19 September 1955

Fauzi, Noer. 1999. Petani dan Penguasa: Dinamika Perjalanan Politik Agraria Indonesia. Yogyakarta: Insis, KPA, dan Pustak Pelajar. Hlm. 124-125

Feith, Herbert 1962. The Decline of Constitutional Democracy in Indonesia. Itacha: Cornell University Press.
1971. The Indonesian Election of 1955. New York: Modern Indonesia Project, Southeast Asia Program, Cornell University.

Fikiran Rakjat, 28 September 1955

Friyanti, Fiska. 2005. "Pelaksanaan Pemilihan Umum dalam Sejarah Nasional Indonesia". Skripsi. Jurusan Sejarah FIS Universitas Negeri Semarang.

Harian Rakjat, 15 Januari 1955.

Harian Rakjat, 23 Mei 1955.

Keputusan Komisi Pemilihan Umum Nomor: 411/Kpts/KPU/Tahun 2014 Tentang Penetapan Hasil Pemilihan Umum Anggota Dewan Perwakilan Rakyat, Dewan Perwakilan Daerah, Dewan Perwakilan Rakyat Daerah Provinsi, Dan Dewan Perwakilan Rakyat Daerah Kabupaten/Kota Secara Nasional Dalam Pemilihan Umum Tahun 2014

Khotimah, Siti. 2003. "Peranan Pers dalam Perjuangan Partai Politik pada Masa Demokrasi Liberal 1950-1959 (Sebuah Tinjauan terhadap Suluh Indonesia dan Harian Rakjat)". Skripsi. Jurusan Sejarah Fakultas Ilmu Sosial Universitas Negeri Semarang.

King, Dwight Y. 1998. Seandainya Sistem Distrik Berlaku pada Pemilu 1955. Dalam http://www.seasite.niu.edu/ indonesian/ Reformasi/Perspektif/ sean45.htm

Kodiran. 1988. "Kebudayaan Jawa". Dalam Koentjaraningrat (ed.). Manusia dan Kebudayaan Indonesia. Jakarta: Penerbit Djambatan. Hlm. 337

Magnis-Suseno, Franz. 1984. Etika Jawa: Sebuah Analisa Falsafi tentang Kebijaksanaan Hidup Jawa. Jakarta: Gramedia.

Moedjanto, G. 1988. Indonesia abad ke 20. Yogyakarta: Kanisius.

Pabottingi, Mochtar. 1998. Menggugat Pemilihan Umum Orde Baru. Jakarta: Yayasan Obor Indonesia.

PCINU Mesir. 2010. NU dan Pemilhan Umum, dalam http://pcinumesir.tripod.com/ilmiah/pusaka/ ispustaka/buku02/004_4.txt diunduh 4 Januari 2010.

Poesponegoro, Marwati Djoned dan Nugroho Notosusanto (ed). 1984. Se- 
jarah Nasional Indonesia Jilid 6. Jakarta: Balai Pustaka.

Ricklefs, M.C. 2005. Sejarah Indonesia Modern 1200-2004. Terjemahan. Jakarta: Serambi.

Said, Tribuana. 1987. Sejarah Pers Nasional dan Pembangunan Pers Pancasila. Jakarta: Haji Masagung.Hlm 94

Sekretariat Negara. 1975. 30 Tahun Indonesia Merdeka 1945-1949. Jakarta: PT. Lamtoro Gung Persada.

Suara Merdeka, 16 Juni 1955

Suara Merdeka, 10 Agustus 1955

Suara Merdeka, 9 September 1955

Suara Merdeka, 10 September 1955

Suara Merdeka, 24 September 1955

Suara Ummat, 3 Oktober 1955

Suara Ummat, 30 November 1955

Suara Ummat, 3 Desember 1955

Suluh Indonesia, 4 Juli 1955

Suluh Indonesia, 5 September 1955

Suluh Indonesia, 7 September 1955
Suluh Indonesia, 15 September 1955

Suluh Indonesia, 26 September 1955

Suparlan, Parsudi. 1977. “Demokrasi dalam Masyarakat Pedesaan". Prisma. No. 2 Februari 1977. Hlm. 65.

Syibly, M. Roem. 2009. Dinamika Politik Jawa Tengah. Dalam http://www.reforminstitute.org/index.php?option $=$ com content\&view $=$ frontpage\&Itemid $=1$ diunduh 2 Januari 2010.

Tempo 13/XXVIII 31 Mei 1999

Undang-Undang No. 7 Tahun 1953 tentang Pemilu

Wahyudi, M. Zaid. 2008. "Pemilu 2009 : Jumlah Pemilih 171.068.667 Orang". Kompas, 25 November 2008.

Wicaksono, Gunawan. 2006. “Peran tentara teritorium IV diponegoro dalam pelaksanaan pemilihan umum 1955 di Jawa Tengah". Skripsi. Jurusan Sejarah FSSR Universitas Sebelas Maret. 
Kampanye dan Pertarungan... - Tsabit Azinar Ahmad

Perolehan Suara DPR dan Konstituante untuk Pemilu tahun 1955 di Jawa Tengah

\begin{tabular}{|c|c|c|c|c|c|c|c|c|c|}
\hline \multirow{2}{*}{ No } & \multirow{2}{*}{ Daerah } & \multicolumn{2}{|l|}{ PNI } & \multicolumn{2}{|l|}{ NU } & \multicolumn{2}{|l|}{ PKI } & \multicolumn{2}{|c|}{ Masyumi } \\
\hline & & DPR & Konst. & DPR & Konst. & DPR & Konst. & DPR & Konst. \\
\hline 1 & Semarang & 24,687 & 29,367 & 82,329 & 48,996 & 143,738 & 140,742 & 4,588 & 5,149 \\
\hline 2 & Kendal & 72,541 & 71,661 & 71,483 & 74,321 & 60,901 & 61,749 & 31,132 & 30,916 \\
\hline 3 & Demak & 41,793 & 41,728 & 100,974 & 109,124 & 39,251 & 39,550 & 5,466 & 4,973 \\
\hline 4 & Purwodadi & 60,175 & 69,009 & 59,935 & 59,880 & 124,028 & 122,384 & 12,752 & 13,800 \\
\hline 5 & Pati & 108,629 & 107,150 & 52,219 & 52,569 & 85,430 & 84,396 & 13,401 & 19,082 \\
\hline 6 & Kudus & 43,927 & 38,262 & 63,007 & 61,354 & 26,998 & 32,683 & 5,449 & 5,574 \\
\hline 7 & Jepara & 45,999 & 53,043 & 110,953 & 105,221 & 19,377 & 21,705 & 10,953 & 10,991 \\
\hline 8 & Rembang & 50,745 & 50,153 & 38,007 & 40,368 & 26,999 & 27,616 & 11,331 & 11,974 \\
\hline 9 & Blora & 73,926 & 78,612 & 29,652 & 33,337 & 80,380 & 77,777 & 12,972 & 14,441 \\
\hline 10 & Pekalongan & 212,915 & 123,427 & 128,732 & 82,251 & 27,190 & 11,727 & 20,025 & 17,167 \\
\hline 11 & Pemalang & 158,156 & 152,335 & 77,653 & 84,969 & 64,260 & 61,737 & 11,879 & 12,126 \\
\hline 12 & Tegal & 132,159 & 141,871 & 78,855 & 86,269 & 32,869 & 34,215 & 53,157 & 54,102 \\
\hline 13 & Brebes & 150,593 & 161,863 & 80,965 & 84,127 & 41,953 & 47,217 & 49,432 & 50,159 \\
\hline 14 & Banyumas & 220,079 & 225,010 & 77,080 & 80,963 & 36,185 & 33,760 & 43,533 & 45,716 \\
\hline 15 & Cilacap & 130,605 & 97,821 & 48,718 & 48,457 & 170,756 & 167,219 & 32,679 & 33,252 \\
\hline 16 & Purbalingga & 115,820 & 120,077 & 55,983 & 58,328 & 8,726 & 9,947 & 51,613 & 55,193 \\
\hline 17 & Banjarnegara & 101,121 & 105,392 & 21,245 & 23,071 & 12,853 & 16,186 & 36,945 & 38,524 \\
\hline 18 & Magelang & 64,400 & 80,532 & 137,027 & 137,320 & 76,452 & 74,860 & 39,468 & 40,020 \\
\hline 19 & Temanggung & 28,176 & 31,033 & 41,009 & 42,942 & 65,764 & 65,612 & 19,625 & 19,853 \\
\hline 20 & Wonosobo & 90,106 & 90,723 & 67,860 & 71,306 & 11,492 & 13,621 & 7,207 & 8,756 \\
\hline 21 & Purworejo & 152,358 & 154,659 & 51,448 & 52,086 & 23,923 & 22,642 & 1,942 & 9,520 \\
\hline 22 & Kebumen & 125,306 & 133,791 & 103,803 & 104,925 & 67,171 & 63,705 & 42,721 & 41,773 \\
\hline 23 & Klaten & 100,190 & 110,236 & 3,867 & 4,041 & 204,296 & 197,019 & 48,407 & 47,671 \\
\hline 24 & Boyolali & 41,438 & 47,817 & 29,934 & 31,148 & 143,565 & 146,024 & 38,701 & 43,918 \\
\hline 25 & Sragen & 131,072 & 124,751 & 1,915 & 2,338 & 27,841 & 39,878 & 40,682 & 36,681 \\
\hline 26 & Sukoharjo & 51,078 & 43,576 & 550 & 398 & 86,689 & 93,621 & 13,888 & 16,095 \\
\hline 27 & Karanganyar & 66,648 & 84,008 & 320 & 631 & 43,182 & 52,729 & 10,658 & 14,757 \\
\hline 28 & Wonogiri & 167,467 & 175,816 & 2,521 & 2,631 & 142,753 & 136,676 & 25,896 & 27,744 \\
\hline 29 & Bantul & 40,820 & 51,864 & 37,983 & 40,249 & 34,287 & 30,940 & 34,838 & 34,871 \\
\hline 30 & Sleman & 47,570 & 55,672 & 26,773 & 28,131 & 35,885 & 34,188 & 30,872 & 29,304 \\
\hline 31 & Kulonprogo & 45,563 & 49,930 & 20,422 & 19,974 & 12,459 & 12,292 & 23,967 & 16,168 \\
\hline 32 & Gunungkidul & 24,801 & 34,011 & 5,703 & 6,741 & 95,732 & 88,080 & 16,017 & 16,608 \\
\hline 33 & $\begin{array}{l}\text { Kab. Semarang } \\
\text { Kab. Peka- }\end{array}$ & 21,452 & 27,641 & 18,882 & 19,700 & 97,053 & 91,727 & 6,390 & 7,154 \\
\hline 34 & longan & 17,842 & 17,586 & 11,968 & 12,321 & 2,540 & 2,777 & 5,891 & 6,212 \\
\hline 35 & Kab. Tegal & 12,106 & 12,531 & 4,267 & 4,907 & 6,637 & 6,261 & 7,037 & 6,930 \\
\hline 36 & Kab. Solo & 31,871 & 37,122 & 1,411 & 2,000 & 75,345 & 70,834 & 15,168 & 13,740 \\
\hline \multirow[t]{2}{*}{37} & $\begin{array}{l}\text { Kab. Yogya- } \\
\text { karta }\end{array}$ & 21,839 & 30,048 & 2,395 & 2,924 & 43,954 & 39,713 & 17,982 & 16,783 \\
\hline & Total & $3,025,973$ & $3,060,128$ & $1,747,848$ & $1,720,318$ & $2,298,914$ & $2,273,809$ & 854,664 & 877,697 \\
\hline
\end{tabular}

Sumber: Antara , 25 Desember 1955 